\title{
Work and play in early childhood education: Views from Nigeria and South Africa
}

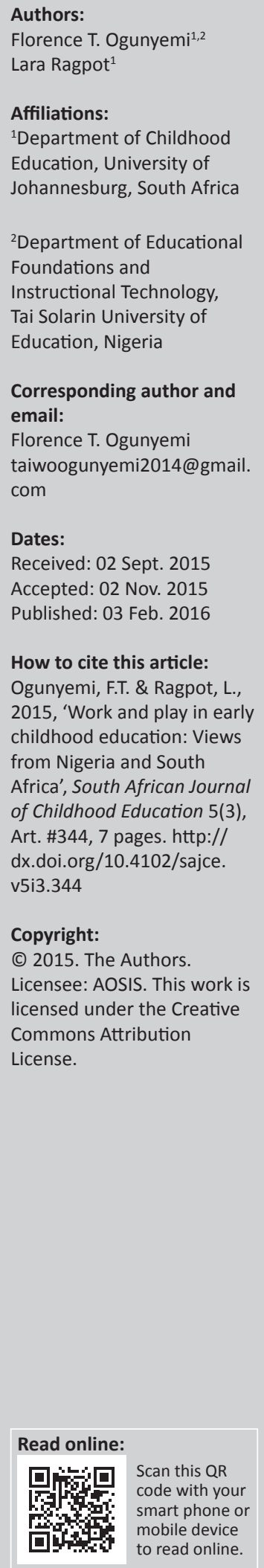

The work reviews the ongoing controversy over work and play within the framework of a constructivist early childhood curriculum. Educators and parents with narrow perception of play view it as mere physical actions of walking, clapping and singing outside class work. However, educators who hold a constructivist epistemological view of child play see play as educative, and possessing ingredients for stimulation that foster an all-round development of children. The paper examines various dimensions of play and work within a constructivist early childhood education paradigm, with special reference to playful learning. The authors argue that teachers of young children need to conceptualize play with a supportive policy and procedural environment that meet the criteria for evaluational, relational and instrumental relevance. Some challenges associated with the use of playful learning in early childhood education centres in Nigeria and South Africa are highlighted.

\section{Introduction}

As concerns for the care and education of children aged 0-8 gain increasing attention worldwide, research into the methods of achieving best results has equally been on the rise (Bodrova, Germeroth \& Leong 2013; Kamerman 2006; UNESCO 2014; Woodhead 2006). One major outcome of these advocacy and research efforts in early childhood care, development and education is the popularity of 'constructivist early childhood education'. This construct, in simple terms, implies the application of the principles of constructivism in the theory and practice of children's education and care especially during their formative years.

At the heart of education with a constructivist epistemological leaning is striking a balance between what can be viewed as 'work' and 'play'. Play is a popular and yet controversial construct amongst early childhood education researchers and teachers, particularly in developing countries such as Nigeria and South Africa. A famous nursery school rhyme in Nigeria betrays the issue at dispute: 'Work while you work and play while you play; to be useful and happy, this is the way'. This rhyme reflects a clear separation of 'play' from 'work'; the former is reserved for the children's break or lunch time, whilst the latter is to be observed within classroom activities. The situation is compounded by pressures from homes. Many parents, including the 'educated' ones, insist that their 2- or 3-year-old children must immediately settle down to the 'serious business of learning' (Durojaiye 1977). In other words, there is widespread belief that nursery school is 'a simple extension of primary school, enabling formal instruction to start a little earlier and therefore ensuring entry to primary school and a headstart on admission there' (Durojaiye 1977:9).

Evidence from research on neuroscience and early learning has, however, shown that the separation of work and play in laying academic foundations for the growing child is misconstrued (Abbas, Othman \& Rahman 2012; Colliver 2011; Cutter-Mackenzie et al. 2014). In particular, constructivist early childhood educators argue that striking a balance between 'work' and 'play' provides the avenues for children not only to explore their environment and build their personality but to also construct knowledge that is unique to them (Bodrova \& Leong 2010; Gupta 2008; Walsh et al. 2010). Nancy Carlsson-Paige illustrates the place of play in childhood learning and, at the same time, laments its diminishing status thus:

Play is the primary engine of human growth; it's universal - as much as walking and talking. Play is the way children build ideas and how they make sense of their experience and feel safe. Just look at all the math concepts at work in the intricate buildings of kindergartners. Or watch a 4-year-old put on a cape and pretend to be a superhero after witnessing some scary event.

But play is disappearing from classrooms. Even though we know play is learning for young kids, we are seeing it shoved aside to make room for academic instruction and "rigour." (cited in Strauss 2015)

Consequently, there is the need to continually navigate the landscapes of the play-versuswork controversy, if scholars are to properly guide the 'future directions of play scholarship 
and policy' (Colliver 2011:13). The paper reviews the benefits and challenges of play and work in early childhood education settings with a focus on Nigeria and South Africa. It conceptualises constructivism with reference to early childhood education. It also examines the relationship between work and play within the purview of a constructivist early childhood curriculum. Lastly, an overview of the challenges and prospects of constructivist early childhood curricula in Nigeria and South Africa is undertaken.

\section{Constructivism as epistemology for early childhood education}

Constructivism is a theory of the process of knowing with roots in philosophy, psychology and cybernetics or communication in organisms (Von Glasersfeld 1995). It is 'a manner of learning that requires participation in an activity' (Sheehy 2002:2). Within the context of early childhood education, Bredekamp et al. (1992) say of constructivism:

Knowledge is constructed as a result of dynamic interactions between the individual and the physical and social environments. In a sense the child discovers knowledge through active experimentation. Central to experimentation is making "constructive errors" that are necessary to mental development. Children need to form their own hypotheses and keep trying them out through mental actions and physical manipulations observing what happens, comparing their findings, asking questions, and discovering answers - and adjust the model or alter the mental structures to account for the new information. (p. 6)

Hence, the core issue in constructivism as a stance for early learning and development is that learners should be given the opportunity to actively process ideas, events and phenomena with which they come into contact to form their own knowledge and that much of this can be carried out playfully. From the philosophical viewpoint, constructivism relies on an epistemology that stresses subjectivism and relativism; the idea that whilst reality may exist separate from experience, it can only be known through an individual's experience, which results in a personally unique reality (Doolittle n.d).

A constructivist position is about how people learn, based on their experience of the world, and based on what they already know. Major variants of constructivism are cognitive (Piaget), sociocultural (Vygotsky), radical (Glaserfeld) and physical (Novak). However, Mahoney (2004) has distilled five elements or principles of the constructivist paradigm as active agency, order, self, social-symbolic relatedness and lifespan development. Most constructivists agree that human experience involves continuous active agency. It is this agency element that 'distinguishes constructivism from forms of determinism that cast humans as passive pawns in the play of larger forces' (Mahoney 2004:362).

The second principle is that much of human activity is devoted to the ordering process; that is, the organisational patterning of experience by means of tacit, emotional meaning-making processes. In the third place, constructivists argue that the organisation of personal activity is fundamentally self-referent or recursive. 'This makes the body a fulcrum of experiencing, and it honours a deep phenomenological sense of selfhood or personal identity' (Mahoney 2004:362). Nevertheless, the self is not an isolated island of 'Cartesian individuality' (Sheehy 2002), because humans exist and grow in living webs of relationships. This point about the role of the environment is particularly emphasised in Vygotskian sociocultural approach to constructivism (Ogunyemi 2012), which, also means that the signs and tools of a sociocultural setting, and the people who use them, are important (semiotic) signifiers in building knowledge. This is the fourth element in Mahoney's analysis: individuals' knowledge cannot be understood apart from their organic embeddedness in social and symbolic systems. Put differently, it means that the knowledge generated is best understood in the context of the social reality (and history) in which the agency is located. In the last analysis, 'all of this active, meaningful, and sociallyembedded self-organization reflects an ongoing developmental flow in which dynamic dialectical tensions are essential' (Mahoney 2004:362). Mahoney concludes that order and disorder coexist in lifelong quests for a dynamic balance that is never quite achieved and associates this dynamism with existentialism. These five themes reflect a constructive view of human experience as one that emphasizes meaningful action by a developing self in complex and unfolding relationships.

Constructivism is regarded as a 'new' paradigm and a reaction to progressivism in philosophy and behaviourism in psychology (Simon 2001). However, elements of the constructivist theory have been around since the time of Socrates, Plato and Aristotle-all of whom spoke about the formation of knowledge in children (Crowther 1997). Therefore, cumulative advocacy and research efforts have only translated into the increasing popularity of constructivist early childhood education (Ogunyemi 2012). Rheta DeVries, drawing upon her extensive research on the application of the Piagetian constructivism in early childhood education, brings out the dynamic interactions amongst constructivist research, theory and practice. She concludes that:

the educational paradigm utilizes the results of research on children's thought and reasoning. For example, errors in child logic and reasoning are recognized as necessary for the construction of correct knowledge - the result of using the intelligence. (DeVries 2004:3)

In particular, the appeal of a self-correctional or 'trial-and-error' strategy largely accounts for the increasing application of constructivism and promotion of play in early childhood education.

Nevertheless, the translation of the constructivist paradigm to practice is not without problems. For instance, Clements (1997) talks of 'myths' being peddled about 'constructivism', which tend to misrepresent the construct. One of such myths is that students should always be actively and reflectively constructing, irrespective of their age or experience. Another myth is that manipulatives (e.g. objects of play such as toys) make learners active all the time, notwithstanding the 
children's interest and to what end they are put. Also, there is the myth of 'constructivist learners' as lonely voyagers, the claim that children learn best when they are left on their own. Again, cooperative learning is sometimes wrongly construed as constructivist. Added is the myth that 'everybody is right!' Clements submits that constructivism goes beyond 'discovery', beyond 'active learners', beyond 'active teaching' and beyond mathematics in books and objects. Whilst noting that constructivism tells us more of how people learn than about teaching, Clements counsels:

Our decisions about teaching and learning should emerge from a solid understanding of educational philosophy. Constructivism is a philosophy of learning, not a methodology of teaching. By repudiating myths and understanding its unique elements, we can use constructivism to transform and improve our teaching. (Clements 1997:200)

Clements' counsel justifies a critical approach to the application of constructivism in early childhood education theory and practice and it reminds the educator of the need to balance a number of factors whilst handling learners in their care. Such (developmental) factors include the child's age, interest and maturity level as well as the resources available in the environment of practice. This need for caution is perhaps most evident in work and play within the curriculum.

\section{Work and play in a constructivist early childhood education curriculum}

The controversy about work and play in early childhood education has a historical origin. In the account of Eliason and Jenkins (2008):

During the end of the $20^{\text {th }}$ century, debate centering on curriculum in early childhood programs created controversy, confusion, and contention. Some curriculum programs stressed content skills such as math, language, reading, and science. These programs advocated direct instruction, workbook exercises, drill and practice, and in general emphasized children's achievement on standardized IQ and readiness tests. Other curriculum developers supported developmentally appropriate practice (DAP), which they believe is in harmony with Piaget's theory (constructivism) and does not rush children into academically rigorous learning before they are ready. This is the child development approach in which work with manipulatives, social interaction, and a more traditional method is advocated. (p. 6)

Bodrova and Leong (2010) have equally attempted an explanation for the controversy. As they succinctly put it:

Most researchers independent of their philosophical orientation seem to agree that including play in early childhood curriculum is a necessary condition for ensuring optimal growth and development of young children. However, the lack of common definition of play makes it hard to provide specific recommendations for curriculum designers and to advocate for preserving play in early childhood classrooms in the face of increasing demands for a focus on academic skills. (p. 3)
There may be no agreement on the specifics of relevant early childhood education curriculum or the dimensions of how to use play to drive the physical, mental, emotional and moral development of children. Nevertheless, play is implicit in the whole-child concept, DAP and constructivism, to which most early childhood educators subscribe.

The whole-child concept provides a framework for thinking about the nutritional, health, physical, mental and emotional needs of the child whilst DAP serves the purpose of guidelines for translating theory to practice. Constructivism tasks the educator on practical activities involved in the dayto-day packaging and implementation of the curriculum. It is at this level of curriculum implementation that the relevance or otherwise of play becomes an issue (Ogunyemi 2012). Without doubt, however, putting the child at the centre of activities designed to improve his or her quality of life does not start with the preschool facility, it begins from the mother's lap and the home environment. Thus, the challenge before caregivers and teachers in preschool facilities may logically suggest building on children's experiences to foster their development.

It is not in doubt that children love to play. Therefore, what may be required is engaging them in activities that lead to new experiences and knowledge through 'playful learning'. In fact, 'including play in early childhood curriculum is a necessary condition for ensuring optimal growth and development of young children' (Bodrova \& Leong 2010:3). Constructivism as an epistemology provides a framework for playful learning in the context of DAP (Walsh et al. 2010). However, inclusion of play alone does not fully solve the problem; there are other underlying issues with which the educator must grapple for success.

The starting point is the conceptual clarification of play. To the early childhood educators who view play as merely being active through the manipulation of concrete objects which are of interest to children, play is not more than 'physical action'. Although children equally learn whilst moving and talking, not all play is meaningful or educative (DeVries 2004). Meaningful plays involve specific kinds of activity that lead to worthwhile ends. Therefore, early childhood play must be well conceptualised beforehand to meet the criteria for evaluational, relational and instrumental relevance (Akinpelu 1982). Evaluational relevance is about the general purpose of play in education whilst the relational narrows it down to the goals of play in comparison with other strategies of early childhood education. Instrumental relevance, essentially, deals with the connection between play and other activities (e.g. reading, mathematics, science) that make up the early childhood curriculum (Ogunyemi 2012).

Play which involves the 'manipulation of concrete objects' for its own sake cannot serve the purpose of meaningful early childhood education. Some children who manipulate guns could be seen as engaged in 'play' in a manner similar to another set of children who 'playfully' throw hard or sharp objects such as stones, sticks and knives at each other. 
Such playful activities are inimical to their own safety and security and the health of the society. For instance, cases of school violence and shootings in the United States and other parts of the world have created gory scenes, including deaths and deformities (Klein 2012; Mncube \& Harber 2013; Wike \& Fraser 2009). A case in Ondo State, Nigeria, in 2010 involved one primary school girl who 'playfully' pulled the trigger of a recovered locally manufactured gun kept in their school premises thereby causing the death of another schoolmate (Ogunyemi 2012). Similar instances in South Africa and elsewhere show that not all forms of 'play' are educative.

An educative play is one which possesses the ingredients for cognitive stimulation that is supportive of human development (DeVries 2004). Variants of such play include physical, dramatic, exploratory, fantasy, manipulative and games-with-rules plays (Ogunyemi 2004). The role of the educator in giving guidance is critical. Piaget and Dewey stress that children are thinking about objects as they are manipulating them; the role of educators is to channel the process towards the development of their thinking faculty DeVries 2004). Piaget's ideas about concrete operations and Dewey's thoughts on experiential learning clearly bring out the import of the emphasis on development-focused objects and strategies of play (Ogunyemi 2012).

Constructivist-minded educators see the child's interest as pivotal to curriculum decisions, including work and play. From the Piagetian perspective, 'interest is central to spontaneous mental actions by which the child constructs knowledge, intelligence, and personality' (DeVries 2004:8). Nevertheless, NAEYC (1990:13), advises that the preschool curriculum does not necessarily have to 'entertain' children; 'instead, children's enjoyment can derive from positive findings about self and meaningful learning as they realize their own progress and growing competence'. This calls for activities that promote the interest and values of children without compromising the requirements for their mental, physical and social-moral development in the application of the playful learning techniques.

It could be argued that 'play' and 'work' for the child are two sides of the same coin (Ogunyemi 2012). Whenever educators claim that play is the child's work, they misinterpret 'DAP as unstructured free play which has little to do with academic such as reading, writing, and arithmetic' (DeVries 2004:8). However, critical factors that enhance success in DAP include 'robust curriculum content; careful attention to known learning sequences (in literacy, mathematics, science, physical education, and other domains); and emphasis on developing children's self-regulation, engagement, and focused attention' (NAEYC 2009:6). Added to these are practices familiar to early childhood educators, such as relationship-based teaching and learning; partnering with families; adapting teaching for children from different backgrounds and for individual children; active, meaningful, and connected learning; and smaller class sizes. (NAEYC 2009:6)
In all this, the need for a balance of work with play clearly suggests itself. Hence, to exclude work from play or vice versa in early childhood, education is to implement a deficient curriculum (DeVries 2004).

Eliason and Jenkins (2008) have analyzed the common misconceptions about play and stress the need to correct them:

To some, it (play) suggests frivolous leisure activities, "killing time," and recreational activities. Play does not provide a concrete, tangible, or academic end product that can be displayed to parents. It is not teacher directed. However, through mature play, children learn and develop skills that will prepare them for academic competence needed in the future. (p. 26)

The mention of 'mature play' underlines the importance of guided freedom in the use of play particularly within a constructivist framework. Similarly, the idea of 'future' does not necessarily mean a distant time; rather, it points to progression in the growing child's competence for advanced learning in line with Piaget's genetic epistemology (DeVries 2004; Piaget 1968). Piaget explains genetic epistemology further in terms of:

attempts to explain knowledge, and in particular scientific knowledge, on the basis of its history, its sociogenesis, and especially the psychological origins of the notions and operations upon which it is based (Piaget 1968:1).

'Good play experiences unite and blend all aspects of development, reaping social, emotional, physical, intellectual, moral, creative, and cultural benefits for young children' (Eliason \& Jenkins 2008:26). Through playful learning experiences, children develop relevant competencies as they are provided opportunities to balance 'work' with 'play'.

Studies by DeVries (2004) have illustrated the interconnectedness of work and play, showing four possible models (A-D) that could be observed in practice. In model A, play is peripherally related to academic learning. The teacher directs affairs in an authoritarian manner with limited facilities for play but reward for academic outcome. Model B presents play as disguised academic work. It is morally shallow with trivial arts and crafts. In model C, play is integrated with social and emotional development. The teacher's role is noninterventionist, warm and nurturing, although sometimes mildly authoritarian. Play materials and activities are abundant but they are often below children's capabilities. It is only under model D that play and work are integrated with social, emotional, moral and intellectual development as emphasised within the constructivist early childhood education perspective. Here, the teacher plays the role of an interventionist or guide to prevent complications or crises. However, such intervention is carried out with warm, nurturing and democratic disposition. Materials for play and related activities are not only abundant but also challenging to the young learners so as to enhance their opportunities for 'constructive mistakes' and make them the drivers of their own learning. DeVries (2004) concludes that classroom types A and B put emphasis on academics, whilst C and D stress development. 
The evidence suggests that there is almost a consensus on constructivist curriculum, DAP and play-based pedagogy in early childhood education in Western countries. For example, a literature survey by Bertram and Pascal concludes that:

Despite differences in the specific curriculum models (e.g., DAP, Froebel, High Scope, Montessori, Reggio Emilia, Steiner, Te Whariki), there was a strong consensus about the curriculum principles for 3-6 year olds' (Walsh et al. 2010:4).

These principles are:

- a child-centred, flexible and individually responsive curriculum

- the importance of working in partnership with parents

- the need to offer broad and relevant learning experiences in an integrated manner

- the importance of play and active, exploratory learning

- an emphasis on social and emotional development; and

- the need to empower the child to be an autonomous, independent learner (Bertram \& Pascal 2002 cited in Walsh et al. 2010:5).

On how the curriculum should be organised, the review further shows that 'most countries used areas of learning, a few used activities, and no country used disciplines or subjects' and that the commonly identified areas of learning included social and emotional; cultural, aesthetic and creative; physical; and environmental. Others were language and literacy, and numeracy. 'Many countries emphasised cultural traditions and aimed to enhance social cohesiveness through the curriculum' but 'three countries emphasised early literacy and numeracy within the early years curriculum (Tasmania, USA, and England)' (Walsh et al. 2010:5). However, it significant to observe that the level of consensus on constructivist early childhood curriculum and pedagogy subsisting in Europe and America is far from the reality in the developing countries of Africa.

\section{Challenges for Nigeria and South Africa}

Promoting what is an 'ideal' constructivist curriculum with play comes with enormous challenges in many developing countries, especially in Nigeria and South Africa, where the drive for early formal learning is strong and the view for economic development as the source of this drive is unabated. Towards this end, the United Nations, through its agencies such as the United Nations Children's Fund and United Nations Educational, Scientific and Cultural Organisation, has been providing technical and financial support for the creation of an enabling environment for qualitative and affordable preschool education particularly within the framework of the Education for All and the Millennium Development Goals. The approaches of these international and multilateral agencies to early childhood care, development and education in many countries in Africa are largely inclined towards the DAP with its implicit constructivist and play-based strategies. However, from the available evidence, it appears that the advocated policy reforms have not fully translated into concrete actions in respect of Nigeria's Early Childhood Care, Education and Development (Ivowi 1996; Maduewesi 2005; Ogunyemi 2012) or the Early Child Development programme in South Africa (Atmore, van Niekerk \& Ashley-Cooper 2012; Storbeck \& Moodley 2011; Williams et al. 2001). In both Nigeria and South Africa, it appears the settings for early childhood care, education and development do not support full expression of child's rights and equity and justice implicit in constructivist early childhood curriculum.

Nigeria's new National Policy on Education (Federal Republic of Nigeria 2013) has segmented preschool education 'into ages $0-4$ years situated in day care or crèches fully in the hands of private sector and social development services' and ages 5-6 (i.e. 1 year of kindergarten), which is to be fully incorporated within the formal sector. In reference to the Universal Basic Education (UBE) Act (Federal Republic of Nigeria 2004), this latter segment shall not only be free but is also compulsory (Federal Republic of Nigeria 2013). However, consistent findings on the state of Nigeria's early childhood education do not suggest any semblance of good quality inputs as canvassed in government's stated objectives and strategies as well as those advocated by the United Nations Children's Fund (Ogunyemi 2012). Evidence of this is noticeable in at least four key areas: problems associated with preschool education curriculum (Aladejana \& Adelodun 2009); the poor quality of, and insufficiently trained, child caregivers/teachers (Oduolowu 2008); low capacity for collaboration at the family and community levels (Uyoata 2014); and policy gap in cost-benefit analysis and quality control (Ibiam, Obiweluozo \& Ugwu 2009). The report of Ibiam, Obiweluozo and Ugwu (2009) tends to summarise the trends across the country. Amongst other things, it was found that the Integrated Early Childhood Development curriculum is not implemented fully in existing pre-primary schools; most of the pre-primary school caregivers/teachers are not prepared for the effective implementation of the Integrated Early Childhood Development curriculum; Nigerian Educational Research and Development Council and United Nations Children's Fund have neither developed nor provided supportive materials for pre-primary education centres; and, although Nigerian Educational Research and Development Council had organised workshops and enlightenment programmes as well as micro teaching practice for parents and caregivers in some locations, several Nigerian communities were yet uncovered.

In South Africa, Early Childhood Development is seen as a comprehensive approach to policies and programmes for children from birth to 9 years of age with the active participation of their parents and caregivers. The South African Department of Education (2001) states clearly that it will only be responsible for children aged 5-9 years, whilst the Department of Social Development will focus on children from birth to 4 year of age and the Department of Health covers all from birth to 9 years in terms of healthrelated issues. Integrated in the South African constitution 
is the Bill of Rights, which makes provision for the socioeconomic rights of children. Although these rights include right to basic education and protection from neglect, abuse and exploitation, the evidence suggests that 'South Africa still has a long way to go to effect quality of life for the majority of her children' (Atmore et al. 2012:1). Two interrelated factors in this respect are the issue of poverty and the effect of HIV-AIDS child-headed homes. Also, despite the fact that there was a major increase in terms of funding (from R335 million in 2003/2004 to R1 billion in 2011/2012), there are discrepancies across the provinces in terms of numbers accessing the funding and the actual amount received with some centres not receiving anything at all (Giese et al. 2011). Giese further shows that the intersectoral service delivery mechanisms are not effective, advocacy effort is weak and there is lack of effective monitoring and evaluation by the government. Seleti (2009) also points out that there is unequal access to economic benefits and resource amenities amongst early childhood development centres. Financial tracking to monitor support for funding in this respect is reported to be equally lacking.

What comes out from the foregoing overview is that the settings for early childhood education in Nigeria and South Africa may not be supportive of constructivist education or the achievement of a meaningful balance between work and play within the curriculum. The situation in both countries is made worse by mass poverty and diseases occasioned in South Africa by the long Apartheid regime (which only ended in 1994) and in Nigeria by years of misrule and mismanagement of the country's wealth since political independence from Britain in 1960. Available data support the possible conclusion that children in the two countries 'not only live in economic poverty but also live in environments deprived in ways beyond the lack of economic resources' (Wright, Diener \& Kay 2000:99). Such children:

do not have the early experiences that we (Western countries) take for granted as prerequisites for formal school. They grow up in families who don't understand the importance of talking and reading to preschool children. Their parents think that learning starts when they enter school. Because they lack these critical early childhood experiences, the chances of them being successful in school are remote. The cycle of poverty continues. (Wright et al. 2000:99)

Obviously, Nigerian and South African governments have a responsibility to break this cycle of poverty. The starting point, of course, is to provide an enabling environment for the emergence and serious implementation of the constructivist early childhood education paradigm.

\section{Conclusion: infusing playful learning}

Playful learning is the fulcrum around which a constructivist early childhood education curriculum revolves. It provides avenues 'for exploring, questioning, and problemsolving' (Eliason \& Jenkins 2008:26). To meet the criteria of evaluational, relational and instrumental relevance, however, playful experiences must be conceptualised to reflect the social, emotional, physical and moral needs of the child as well as the policy aspirations of the society. In balancing for play and work, therefore, a constructivist early childhood education curriculum should be comprehensive, dynamic and also eclectic. Equally important is the complementary role of the family. Parents should be educated to drop the age-long prejudices against play in early childhood education centres.

In the challenge of creating an enabling, 'play-rich' environment for early childhood education in Nigeria and South Africa, the policies must contend with a number of issues. We would argue that these include wrong perception about the value of play by stakeholders, incompetent educators, who are not informed about play as pedagogy, lack of facilities, inadequate funding and/or monitoring, dominance of private sector, policy inconsistency, and poverty and diseases. Governments of both countries would need to go beyond policy formulation and legislation to radically address these and related challenges for the effective implementation of constructivist early childhood curricular practices built around playful learning.

\section{Competing interests}

The authors declare that they have no financial or personal relationships, which may have inappropriately influenced them in writing this article.

\section{Authors' contributions}

F.T.O. (University of Johannesburg \& Tai Solarin University of Education) and L.R. (University of Johannesburg) contributed equally to the writing of this article.

\section{References}

Abbas, M.Y., Othman, M. \& Rahman, P.Z.M.A., 2012, 'Pre-school classroom environment: Significant upon childrens' play behaviour?', Procedia-Social and Behavioural Sciences 49, 47-65.

Akinpelu, J.A., 1983, Relevance in education (An Inaugural Lecture delivered at the University of Ibadan on Tuesday, 19th April, 1983), University of Ibadan Press, Ibadan.

Aladejana, F.O. \& Adelodun, A.O., 2009, 'An assessment of quality of early childhood education in south-west zone of Nigeria', in Readings in early childhood and Universal Basic Education, pp. 255-272, Lantern Books, Accra, Ghana.

Atmore, E., van Niekerk, L. \& Ashley-Cooper, M., 2012, Challenges facing early childhood development sector in South Africa, A Research report on Early Childhood Development to the National Development Agency (NDA), viewed on 15 January 2015, from http://www.nda.org.za/docs/Challenges-facing-ECDSector-in-SA-Prof-Atmore.pdf

Bodrova, E., Germeroth, C. \& Leong, D.J., 2013, 'Play and self-regulation: Lessons from Vygotsky', American Journal of Play 6(1), 111-123.

Bodrova, E. \& Leong, D.J., 2010, 'Curriculum and play in early childhood development', in Encyclopedia on early childhood development, Centre of Excellence for Early Childhood Development, viewed on 20 December 2010, from http://www.enfantencyclopedie.com/Pages/PDF/Bodrova-LeongANGxp.pdf

Bredekamp, S., Knuth, R.A., Kunesh, L.G. \& Shulman, D.D., 1992, What does research say about early childhood education?, North Central Regional Educational, Oak Brook.

Clements, D.H., 1997, 'Constructing constructivism', Teaching Children Mathematics 4, 198-201.

Colliver, Y.J., 2011, 'State of play: Five debates that characterise play literature', Paper presented at the Australian Association of Research in Education. Annual Conference, Hobart, 2011, viewed on 15 January 2015, from http://www.aare. edu.au/data/publications/2011/aarefinal00233.pdf

Crowther, D.T., 1997, 'Editorial', Electronic Journal of Science Education 2, 2, viewed on 15 June 2010 from http://www.aapt.org/pubs.catalog/pubs.html 
Cutter-Mackenzie, A., Edwards, S., Moore, D. \& Boyd, W., 2014, Young children's play and environmental education in early childhood education, Springer Briefs in Education, viewed on 20 December 2014, from http://dx.doi.org/10.1007/9783ducation, viewed

DeVries, R., 2004, 'What is constructivist about constructivist education?', The Constructivist 15, 1.

Doolittle, P.E., n.d., 'Constructivism and online education', viewed on 20 May 2010 from http://www.trainingshare.com/resources/doo2.htm

Durojaiye, S.M., 1977, Practical methods for nursery schools, University Press Ltd., Ibadan.

Eliason, C. \& Jenkins, L., 2008, A practical guide to early childhood curriculum, 8th edn., Pearson Education, Inc., Upper Saddle River.

Federal Republic of Nigeria, 2004, National policy on education, NERDC Press, Lagos. Federal Republic of Nigeria, 2013, National policy on education, NERDC Press, Lagos.

Giese, S., Budlender, D., Berry, L., Motlatla, S. \& Zide, H., 2011, Government funding for early childhood development: Can those who need it get it?, llifa Labantwana, South Africa, viewed on 12 January 2015, from http://ilifalabantwana.co.za/wp content/uploads/2014/10/Government-Funding-for-ECD-can-those-who-need-itget-it.pdf

Gupta, A., 2008, 'Vygotskian perspectives on using dramatic play to enhance children's development and balance creativity with structure in the early childhood Classroom', Early Child Development and Care 1-13.

Ibiam, J.U., Obiweluozo, E.P. \& Ugwu, G.C., 2009, 'Integrated early childhood development of the total man', Nigerian Journal of Curriculum Studies 16(2), 71-79.

Ivowi, U.M.O., 1996, 'Preface', in FGN/UNICEF (ed.), Early child care project in Nigeria: Training manual in early child care, Nigerian Educational Research and Development Council \& United Nations Children's Fund, Lagos.

Kamerman, S.B., 2006, 'A global history of early childhood education and care', pape commissioned for the EFA Global Monitoring Report 2007, Strong Foundations: Early Childhood Care and Education, UNESCO, Paris.

Klein, J., 2012, The bully society: School shootings and the crisis of bullying in America's schools, NYU Press, New York, viewed on 15 January 2015, from http://www. nyupress.org/bullysociety/dataonschoolshootings.pdf

NAEYC, 1990, Guidelines for appropriate curriculum content and assessment in programs serving children ages 3 through 8 , A position statement of the National Association for the Education of Young Children and the National Association of Early Childhood for the Education of Young Children and the National Association of Early Childhood Specialists in State Departments of Education, Adopted November 1990, viewed on
12 July 2014, from http://www.naeyc.org/files/naeyc/file/positions/PSCAG98.pdf

NAEYC, 2009, Position statement: Developmentally appropriate practice, 3rd edn. National Association for the Education of Young Children, Washington, DC viewed on 12 July 2014, from https://www.naeyc.org/files/naeyc/file/positions/ position\%20statement\%20Web.pdf

Maduewesi, E.J., 2005, Benchmarks and global trends in education, Dasylva Influence Enterprises, Benin City.

Mahoney, M.J., 2004, 'What is constructivism and why is it growing?', Contemporary Psychology 49, 360-363.

Mncube, V. \& Harber, C., 2013, The dynamics of violence in schools in South Africa: Report, University of South Africa, Muckleneuk, Pretoria, viewed on 15 January 2015, from http://www.unisa.ac.za/contents/colleges/col_education/docs/ The\%20Dynamics\%20of\%20Violence\%20in\%20South\%20African\%20schools.pdf

Oduolowu, E.A., 2008, 'Investigating young children's informal opportunity for learning values', The Social Sciences 3(1), 51-56.
Ogunyemi, F.T., 2004, 'Play facilities in selected nursery/primary schools: Implications for assuring quality in early childhood education', Journal of Educational Focus 5 , for assuring $116-127$.

Ogunyemi, F.T., 2012, 'Epistemological relevance of constructivism in early childhood education in Nigeria', PhD thesis, University of Ibadan.

Piaget, J., 1968, Genetic epistemology, a series of lectures delivered by Piaget at Columbia University, Columbia University Press, translated by Eleanor Duckworth, viewed on 30 November 2015, from https://www.marxists.org/reference/ subject/philosophy/works/fr/piaget.html

Seleti, J., 2009, 'Early childhood development in South Africa: Policy and practice', paper presentation for the World Bank Technical Workshop of the Africa Early Child Care Development Initiative, Zanzibar, 26-28th October.

Sheehy, M., 2002, 'Illuminating constructivism: Structure, discourse, and subjectivity in a middle school classroom', Reading Research Quarterly 57(8), 278-308.

Simon, S.D., 2001, 'From neo-behaviourism to social constructivism: The paradigmatic non-evolution of Albert Bandura', Unpublished thesis, Bachelor of Arts Honors, Division of Educational Studies, Faculty of Emory College of Emory University.

South African Department of Education, 2001, Education white paper 6: Building an inclusive education and training system, Department of Education, Pretoria.

Storbeck, C. \& Moodley, S., 2011, 'ECD policies in South Africa - What about children with disabilities?', Journal of African Studies and Development 3(1), 1-8, viewed on 15 January 2015, from http://www.academicjournlas.org/JASD

Strauss, V., 2015, 'A childhood development expert on how "twisted" early education has become', viewed on 30 November 2015, from http://www.independent. co.uk/news/education/a-childhood-development-expert-on-how-twisted-earlyeducation-has-become-a6750271.html

UNESCO, 2014, Teaching and learning: Achieving quality for all, United Nations Educational, Scientific and Cultural Organisation, Paris.

Uyoata, U.E., 2014, 'Quality school learning environment as a mediator in the child's right to live, develop and learn', in O.J. Ehindero \& F.O. Aladejana (eds.), Reading in early childhood and Universal Basic Education, pp. 177-187, Lantern Books, Accra, Ghana.

Von Glasersfeld, E., 1995, Radical constructivism: A way of knowing and learning, Falmer, London.

Walsh, G., Sproule, L., McGuinness, C., Trew, K. \& Ingram, G., 2010, Developmentally appropriate practice and play-based pedagogy in early year's education A literature review of research and practice School of Psychology, Queen's University Belfast Stranmillis University College, viewed on 20 June 2014, from http://www.nicurriculum.org.uk/docs/foundation_stage/eye_curric_project/ evaluation/Literature_Review.pdf

Williams, T., Samuels, M., Mouton, J., Ratele, K., Shabalala, N., Shefer, T. \& Strebel, A., 2001 , The nationwide audit of ECD provisioning in South Africa, Department of Education, Pretoria, South Africa, viewed on 15 January 2015, from https://www. westerncape.gov.za/text/2003/national_audit_ecd.pdf

Wike, T.L. \& Fraser, M.W., 2009, 'School shootings: Making sense of the senseless', Aggression and Violent Behaviour 14, 162-169.

Woodhead, M., 2006, 'Changing perspectives one early childhood: Theory, research and policy', Background paper prepared for the Education for All Global Monitoring Report 2007, Strong Foundations: Early childhood care and education, UNESO, Paris

Wright, C., Diener, M. \& Kay, S.C., 2000, 'School readiness of low-income children at risk for school failure', Journal of Children \& Poverty 6(2), 99-117. 